卵サイズと幼体の生存価、特に淡水エビ

2 種幼生の飢餓耐性に関連して'”

益子計夫

(帝京大学医学部動物学教室)

\begin{abstract}
The relationship between egg size and larval survival with special reference to starvation tolerance in two freshwater prawns
\end{abstract}

\title{
Kazuo MASHIKO
}

Department of Zoology, Faculty of Medicine, Teikyo University, Hachioji, Tokyo 192-03, Japan

\section{1.はじめに}

適応戦略論的視点によれば、一腹における卵サイズと卵数は 限られた資源 (卵物質総量) の最適配分の問題として把えられ、 配分のしかたによって大卵少数産もしくは小卵多数産の繁殖形 態の違いを生ずるものとされている (Pianka 1978, 伊藤 1983, 岸 1978 など)。その配分決定に際して、評価の基軸となるのは、 たとえば卯サイズの大型化（子1個体あたりの投資量の増大） においては、数は少ないが、生存確率 (適応度)の高い幼体の 産出が期待できるという認識である(Smith \& Fretwell 1974, 篇佐 1981, など; 図 1 参照)。しかし、大卵少数産によって生 じた大型幼体は一般に高い生存率をもつというだけのととであ れば、（個体群の安定性を想定する限り）トートロジーにすぎ ないのであるから、てのような論議においては、卵 (幼体) サ イズとその生存率との間では、具体的にいかなる生態的条件に おいて、どのような形で相互関連性が発揮されるのか、あるい はされないのか、が問題とされるのでなければなるまい。環境 条件によっては、前述の一般的認識とは反するような局面もあ るにちがいない。

たとえば、魚によるプランクトン餌生物の捕食は、大きさが

1) 本稿は、ベントス個体群の異質性に関する研究集会 (1985. 11. 25 26, 東大海洋研) での講演内容の一部についてとり まとめたものである。

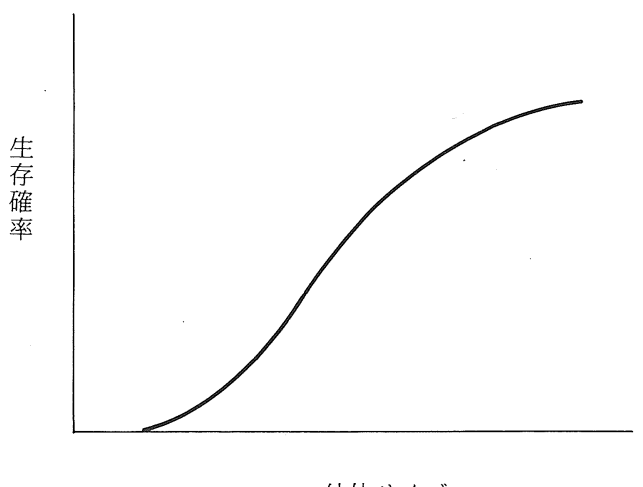

幼体サイズ

図 1 幼体サイズと幼体の適応度との間で一般的に 予測されている関係。個々の幼体の生存確率は 個体あたりの親の投資量の増加とともに増加す るととを示す 1 つのパターン。

梕められる、あるサイズ以上のものについて選択的になされて おり（平野・大島 1963, Lynch 1977, Werner 1974 )、このサ イズ選択的捕食は、しばしば浮遊性甲殻類の死亡要因の主要な 部分を占めるに至っていると考えられている (Brooks \& Dodson 1965, Brambilla 1982, Dodson 1974 )。乙のような被食 
動物群においては、体サイズの大きいととによりむしろ生存率 の低下を招き、小さい体サイズが有利となる場合もあるであろ う(Lynch 1980)。

本稿では、卵 (幼体) サイズと幼体の生存率との関係を把握 するための 1 つの試みとして、幼体の飢餓而性に着目して行っ た、淡水エビ 2 種に関する実験結果に沿っての若干の論考をす すめることとしたい。なお、淡水エビ類では卵（肧）のみによ る独立生活はなく、ふ化まで親に保護されているので、特別な
場合を除いて卵サイズと幼体サイズは同義語と考えてよいと思 われる。

\section{2.スジエビ2 群の飢餓耐性}

スジエビ (Palaemon paucidens) に顕著な卵サイズ変異の あることは、地理的に隔った地方個体群間 (上田 1970, Nishino 1980 ) や、同一水系内の隣接個体群間（Mashiko 1982, Chow \& Fujino 1985 ) で知られている。表 1 は 2 群の異なっ

表 1 スジエビ大型 (平均体長 $4.77 \mathrm{~mm}$ )、小型 (同 $3.88 \mathrm{~mm}$ ) ふ化幼生の、 水温 $20^{\circ} \mathrm{C}$ 絶食条件下に打引る平均生存日数と到達ステーシ (Mashiko, $1985)$ 。到達ステージは供試個体の過半数が到達した最終発育段階で 示してある。

\begin{tabular}{lccc}
\hline & 大型幼生 & & 小型幼生 \\
\cline { 2 - 3 } 平均生存日数 & 8.0 & 5.2 \\
到達ステージ & 第 4ゾェア期 & & 第 3ゾェア期 \\
\hline
\end{tabular}

た体サイズのふ化幼生 (zoea) について、絶食条件下に打ける 生存日数と到達発育ステージとを示したものである。材料は相 模川に生息する大卵産出個体群抢よび小卵産出個体群 $(M a-$ shiko 1983) より得られた。明らかに、大型幼生の絶食下生存 時間は長く（小型幼生の約 1.6 倍）、飢餓耐性の大きいととが わかる。また、絶食条件下でも幼生は脱皮を重ねるだめ、大 型幼生は小型幼生に較べてより進んだ発育ステージに到達する ことが可能となる。大型の卵から生ずる大型幼体の高い飢餓耐 性は、他のいくつかの水生生物種での種内比較でも報告されて いる(たとえば、Kraeuter $\underline{\text { et }} \underline{\text { al. }}$. 1982, Tessier $\underline{\text { et }} \underline{\text { al }}$. 1983, Blaxter \& Hempel 1963, Bagenal 1969,など)。

\section{3. モデルによる検討}

ところで、飢餓耐性の上昇は体サイズの大型化にともなう必 然のなりゆきなのであろうか。体サイズの異なる個体間で、飢 餓而性 (以下特にてとわりのない限り、絶食条件下での生存時 間を意味することとする) に差異を生ずる場合、2つの要因が 考えられる。第 1 は、大型個体における相対的に低いエネルギ 一代謝率 (体サイズ効果) によるものであり、第 2 は利用でき るエネルギー含有量 (卵黄貯蓄量) の違いによるものである。

一般に、個体の生体量（体重）Wと標準代謝量 $\mathrm{R}$ との関係は $\mathrm{R}=\mathrm{a} \cdot \mathrm{W} \mathrm{k}$

の関係式 (Kleiber's rule)で表示できる。aは代謝水準を示 す定数、 $\mathrm{k}$ は通常 0.75 内外の值をとる定数である (Schmidt -
Nięsen 1973, Robinson et $\underline{\text { al }} .1983)$ 。乙てで、ある個体が 出生時に保有するエネルギー量を $\mathrm{E}_{0}$ とすると、 $\mathrm{t}$ 時間後の工 ネルギー含有量 $\mathrm{E}_{\mathrm{t}}$ は、

$$
\begin{aligned}
\mathrm{E}_{\mathrm{t}} & =\mathrm{E}_{0}-\mathrm{R} \cdot \mathrm{t} \\
& =\mathrm{E}_{0}-\mathrm{a} \mathrm{W}_{0} \mathrm{k}_{\mathrm{t}}
\end{aligned}
$$

で近似できる。 $\mathrm{W}_{0}$ は出生時の体重である。絶食時には a の值 が平時より低下する場合のあるてとが知られている ( I keda, 1971 )が、仮にあったとしても低下率は体サイズに依存しない と考えられるので、こてでは特に問題とはなるまい。

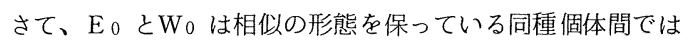
比例的関係にあるとみなしうるのて

$$
\mathrm{W}_{0}=\mathrm{b} \cdot \mathrm{E}_{0}
$$

(3)と(4)より

$$
\mathrm{E}_{\mathrm{t}}=\mathrm{E}_{0}-\mathrm{cE}_{0} \mathrm{k}_{\mathrm{t}}
$$

が得られる。 bと c は定数である。 $\mathrm{E} t$ を $\mathrm{E} 0$ に対する比の形 で示すと(5)式は、

$$
\frac{\mathrm{E}_{\mathrm{t}}}{\mathrm{E}_{0}}=1-\mathrm{cE}_{0} \mathrm{k}^{-1} \mathrm{t}
$$

となり、ての関係を図示したのか図 2 である。大型個体では、 相対的に低いエネルギー消費のため、よりなだらかな傾きをも つ右下がりの直線となる。てのようなパターンは、前述のスジ エビ 2 群幼生に関して、縦軸に総炭素含有量をとるととによっ て実際に得られている(Mashiko，1985)。

図 2 で、大型、小型の両幼体がともに相対エネルギー含有值 


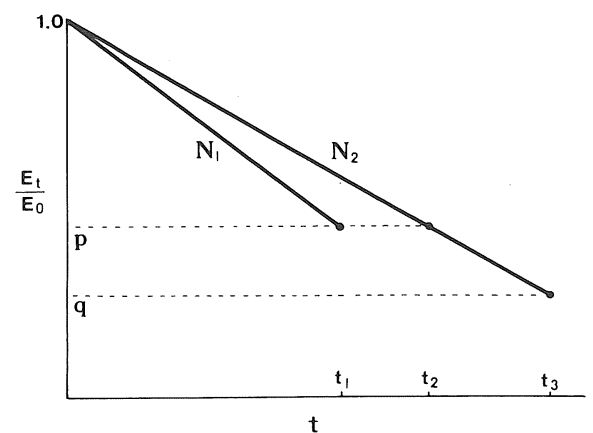

図 2 出生後の時間経過 $(\mathrm{t})$ にともなう、相対的工 ネルギー含有值 $\left(\mathrm{Et} / \mathrm{E}_{0}\right)$ の変化を示すグラフ モデル。大型幼体 $\left(\mathrm{N}_{2}\right)$ は相対的に低いエネル ギー消費率のため、小型幼体 $\left(\mathrm{N}_{1}\right)$ よりなだら かな傾きをとるものと予測される。

$\mathrm{p}$ で死亡するものとすると、生存時間の差 $\mathrm{t}_{2}-\mathrm{t}_{1}$ がエネルギ 一代謝に打ける体サイズ効果を反映しているものと考えるとと ができる。 pの值としては、たとえば体重比を尺度とすると、 多くの動物で 0.5 に近い值になるといわれている (Chossat's rule; Peters 1983 )。乙てで(6)式より

$$
\frac{\mathrm{E}_{\mathrm{t}}}{\mathrm{E}_{0}}=1-\mathrm{cE}_{0} \mathrm{k}^{-1} \mathrm{t}=\mathrm{p}
$$

とおくと

$$
\mathrm{t}=\frac{1-\mathrm{p}}{\mathrm{c}} \mathrm{E}_{0} 1-\mathrm{k}
$$

となり、エネルギー消費レベル $\mathrm{p}$ で死亡する場合の生存時間を 表わす。この式はThrelkeld（1976)か勤物プランクトンの飢 餓而性を推定するのに用いた理論式と同型のものとなる。更に 図 2 で、大型個体は利用可能なエネルギーを相対的に多く含有 していたため、より多量のエネルギー消費が可能となり、たと えば $\mathrm{q}$ の段階にいたって死亡するものとすると、そのような延 長効果は $\mathrm{t}_{3}-\mathrm{t}_{2}$ で表わされる。

ところで(7)式は、 $\mathrm{E}_{0}$ （もしくは体重W $\mathrm{W}_{0}$ ）がm倍になれば、 生存時間 $\mathrm{t}$ はこの体サイズの違いのみによって、 $\mathrm{m}^{1-\mathrm{k}}$ 倍とな るととを意味する $\left(\because\left(\mathrm{mE}_{0}\right) 1-\mathrm{k} / \mathrm{E}_{0} 1-\mathrm{k}=\mathrm{m} 1-\mathrm{k}\right)$ 。た とえば $\mathrm{k}=0.75$ の值 (スジエビ 2 群幼生間でもてれに近い值 が得られている）を採用して、前述のスジエビ 2 群幼生の生存 時間の違いを推定してみると、大型幼生は小型幼生の 1.17 倍 (出生時の総炭素含有比 1.85 を使用) あるいは 1.14 倍 (同乾重 比1.71を使用) の值か得られる。しかし、これらの值は実際の 約 1.6 倍の違いに比較して小さすぎ、大型幼生の高い飢餓耐性 を十分に説明するものではない。同様にして、たとえば 3 倍の $\mathrm{E}_{0}$ 比のもとであっても、生存時間は 1.3 倍程度にしかならな
いのである。別の角度からの検討によれば、スジエビ 2 群幼生 間の顕著な飢餓而性の違いは、前にあげた第 2 の要因、すなわ ち利用可能なエネルギー含有量 (卵黄成分量) の差異に大きく 依存していたてとが示唆されている。(Mashiko 1985 )。

てのように見てくると、飢餓而性の大小を比較するときに着 目しなければならないのは貯蔵エネルギーの含有量であり、た とえばThrelkeld (1976) が関連づけを試みたような単なる体 サイズの大小ではないととが言えるであろう。事実、Ciechomski (1966)はカタクチイワシ (Engraulis anchoita)の体 サイズの異なるふ化稚魚間 (卵体積比で約 2 倍) で、飢餓耐性 （生存時間）にほとんど差異のないてとを報告している。一方 淡水乏ジンコ(Daphnia magma) ふ化幼生間では、体サイズ に差がなくとも含有卵黄量の違いによって 2 倍もの飢餓耐性の 開きがでてくる(Tessier et al. 1983 )。従って、次のてとは 強く認識されるべきであろうと思われる。つまり、幼体の体サ イズ変異には飢餓耐性の増加に直接結びつく方向への変化（体 サイズの増加にともなうアロメトリックな卵黄量の増加）と、 そうではない変化（プロポーシナルな卵黄量の増加、もしくは 非増加）とがありえ、それぞれに適応的意味があるとすれば、 自ずと異なった環境要因との対応関係 (生活史戦略) を想定せ ねばなるまい。海産無せきつい動物では、卵黄量の変化はしば しば発生様式の変更にまで結びついているてとが知られている ( 菊池, 1981)。

\section{4. 飢餓耐性の尺度}

前節までは、絶食条件下で長い生存時間をもつ場合を飢餓耐 性が大きいとして話しをすすめてきだ。こてでは、テナガエビ (Macrobrachium nipponense) 幼生を例にして、飢餓耐性 の大小を示す民度について論じておく。実験材料には、相模川 の河口域に生息する小卵産出個体群からの小型子化幼生 (1.48 $\pm 0.05 \mathrm{~mm}$; 平均体長士S. D. ）抢よび同河川淡水域に生息する 大卯産出個体群からの大型子化幼生 ( $2.09 \pm 0.08 \mathrm{~mm}$ ) を用い た。2群の卵サイズ変異等については別の報文 (Mashiko $1983 a, b, c)$ を参照されたい。2 群幼生については生息場所 の塩分濃度が異なると考えられるので、種々の塩分濃度を実験 的に設定した。幼生は 1 腹毎 40 個体を $500 m \ell$ ビーカーに収容し、 前述のスジエビの場合と同様にして、時間経過にともなう死亡 個体の出現とその発育ステージを調べた。

両群の幼生はともに40\%程度の希釈海水 (人工海水) で最も 良い生存を示した（図３）。乙れはそのような希哷海水中で個 体維持にかかわるエネルギー代謝が最低になる事実（未発表資 料 ) と関係しているものと思われる。との"最適”塩分濃度で 比較すると、両幼生間では生存日数にほとんど差が認められな い。両極端の塩分環境のもとでは差異が認められるが、てれは 高塩分もしくは低塩分に対する両者の調節能力の違いを反映し ているもののように思われる（Mashiko 1983 b)。 


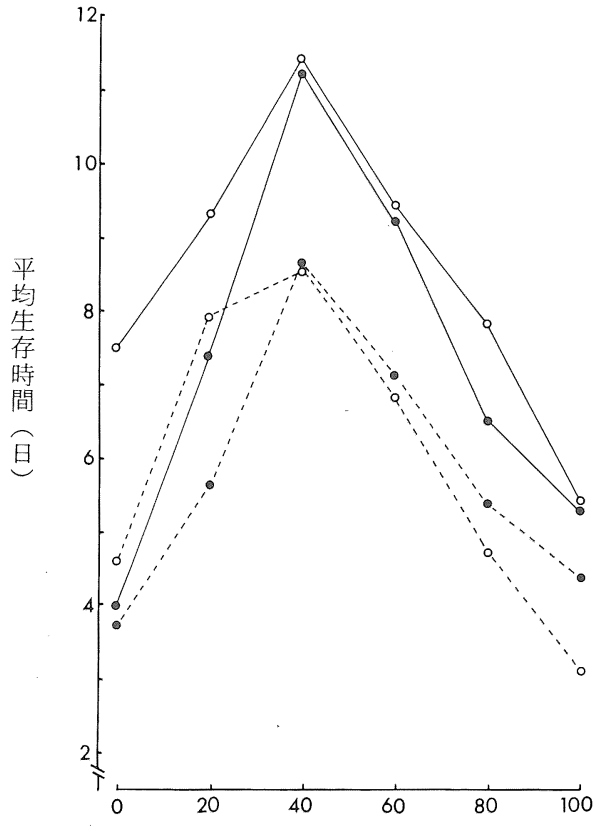

海水濃度 $(\%)$

図3テナガエビ大型（白ぬき丸）、小型（黒丸） ふ化幼生についての水温 $20^{\circ} \mathrm{C}$ (実線) および $25^{\circ} \mathrm{C}$ (点線)、絶食条件下における種々の海水 濃度のもとでの平均生存時間 (日)。海水濃度は 人工海水原液 ( J a marin) 在 $100 \%$ 海水として 他 4 段階に希釈して用いた（ $0 \%$ は純淡水）。 各生存時間は、 3 個体の親 $\left(25^{\circ} \mathrm{C}\right)$ もしく 1 個体の親 $\left(20^{\circ} \mathrm{C}\right)$ から得られた幼生についての 平均值で示した。
ところで、表 2 は絶食条件下で両幼生か椡達した発育ステー ジ毎の生存率を示したものである。小型幼生はすべてが第Пゾ エア期で死滅するのに対し、大型幼生は多くが第刲ゾェア期に 達し（ $20 \sim 60 \%$ 海水中）, 大型幼生の高い生存率は明らかで ある。生存時間では差が認められないのに、発育ステージで違 いが生ずる原因は何であろうか。これは、兩幼生間で本来の発 育速度に違いがあることによるのである。たとえば、ふ化から 次の脱皮までに要する時間は、小型幼生で $2.00 \pm 0.00$ 日 (平 均土S. D. , $\mathrm{n}=14$ broods ) であるのに対し、大型幼生では $1.67 \pm 0.49$ 日 $(\mathrm{n}=12)$ と有意に $(\mathrm{p}<0.025)$ に短くなっ ている ( 水温 $25^{\circ} \mathrm{C} 、 40 \%$ 希勫海水中 )。乙のような脱皮周期 の違いは、サイズの異なる、他のテナガエビ地方個体群からの 幼生に関する飼育実験でも報告されている（Ogasawara et al .1979 )。結局、発育速度に変更が扔てている場合には、 生存時間のみによる比較では不十分であり、発育到達ステージ を考慮しなければならないと言えるであろう。

\section{5。飢餓耐性と生存価}

スジエビ、テナガエビ幼生においては、尺度を正しくとるな らば、大型個体は飢餓条件において高い生存力を示すととがわ かった。しかし、てのてとが直ちに野外での大型幼生の高い生 存率 (適応度) を意味するものではない。そのためには、飢餓 耐性の上昇か野外での生存率の増大に何らかの貢献をなしてい るととを示さねばならない。魚類では、椎仔死亡の主因は捕食 と飢餓であると言われている(Mann \& Mills 1979)が、現 在のところ焱水エビ類ではそれらについての知見はほとんぞ得 られていないようである。従って、高い飢諓而性はどのような 局面で実際的意味をもちうるか、その可能性について簡単に述 べておくとととしたい。

一般的には、水塊中での食物分布が時間的・空間的に不連続 な場合には、絶食下での長い生存時間が生存確率の上昇をもた

表 2 テナガエビ 2 群子化幼生の、水温 $25^{\circ} \mathrm{C}$ 絶食条件下に扔ける各発育 ステージ（ I 〜III ; 第 1〜第 3ゾェア期 ) までの生存率 (\%)。海水濃 度、供試親個体数については図 3 の場合と同様。

\begin{tabular}{|c|c|c|c|c|c|c|}
\hline \multirow{2}{*}{ 海水濃度 (\%) } & \multicolumn{3}{|c|}{ 大型幼生 } & \multicolumn{3}{|c|}{ 小型幼生 } \\
\hline & I & II & III & I & II & III \\
\hline 0 & 100 & 100 & 3.4 & 100 & 100 & 0 \\
\hline 20 & 100 & 100 & 55.4 & 100 & 100 & 0 \\
\hline 40 & 100 & 100 & 79.2 & 100 & 99.1 & 0 \\
\hline 60 & 100 & 99.1 & 51.3 & 100 & 99.1 & 0 \\
\hline 80 & 100 & 97.4 & 10.5 & 100 & 100 & 0 \\
\hline 100 & 100 & 68.6 & 1.3 & 100 & 99.2 & 0 \\
\hline
\end{tabular}


らすであろうことは想像に難くない。ただ、スジエビ、テナガ エビの大型幼生で注目されることは、それらか絶食条件下で単 に長時間生きながらえているというのではなくて、より進んだ 発育ステージに到達している(あるいは、そのポテンシャリテ ィを内包している) という事実である。発育の進んだ幼生ほど 機能的であり、従って食物穫得能力も高いと考えられるので、 このような性質は初期䬣料として適した食物の少ない環境では 有利になるものと思料される。乙れは子にとっての食物の得難 さ（伊藤 1978）に通ずる一面かもしれない。

淡水エビ類のなかには、親は河川上流域に生息し、そてで成 熟・産卵するが、ふ化後の浮遊幼生は河川を流下し、河口域に 達して摂䬣を開始するという生活史を送るものが少なからず知 られている。そのような淡水エビ数種についての比較をすると 幼生の絶食条件下での生存時間 (卵黄消失までの期間に相当) と、野外における河口までの流下時間との間に関連性が認めら れるという (Balasundaram \& Pandian 1982)。非摂餌幼生 による流下・分散は、河口域にまで範囲を広げなくとも、河川 を生息の場とし、浮遊幼生期をもつ淡水エビ類一般についてあ る程度通じるもののようにみえる（諸喜田 1979)ので、その 際高い飢餓而性をもつととは有利であろう。相模川では流水域 にスジエビ大型幼生産出個体群がみとめられるが ( Mashiko 1982.)、事実そのような現象を反映したものであるかどうか、 今後幼生生態が解き明かされることが望まれる。

本研究の一部は文部省科研費 ( N N . 59740328) に拠った。

\section{文献}

Bagenal,T.B., 1969. Relationship between egg size and fry survival in brown trout Salmo trutta L.J. Fish. Biol., 1:349-353.

Balasundaram, C. \& T.J. Pandian, 1982. Yolk energy utilization in Macrobrachium nobilli (Henderson \& Mathai).J. Exp. Mar. Biol. Ecol., 61:125-131.

Blaxter, J.H.S.\&G. Hempel, 1963. The influence of egg size on herring larvae ( $\underline{\text { Clupea }}$ harengus L.).J. Cons, Cons. Int. Explor. Mer., 28:211-240.

Brambilla, D.J., 1982. Seasonal variation of egg size and number in a Daphnia pulex population. Hydrobiologia, $97: 233-248$.

Brooks, J. L. \& S.I. Dodson, 1965. Predation, body size, and composition of plankton. Science, 150:28-35.

Chow, S.\&Y. Fujino, 1985. Biochemical evidence of two types in the fresh water shrimp Palaemon paucidens inhabiting the same water system. Bull. Jap. Soc. Sci. Fish, 50:1451-1460.

Ciechomski,J.Dz., 1966. Development of the larvae and variation in the size of eggs of the Atlantic anchovy, Engraulis anchoita Hubbs and Marini. J.Cons., Cons. Int. Explor. Mer., 30:281-290.

Dodson, S.I., 1974. Zooplankton competition and predation: An experimental test of the size-efficiency hypothesis. Ecology, 55: 605-613.

平野礼次郎・大島泰雄, 1963 . 海産動物幼生の飼育とその慨 料について。日水誌，29:282-297.

Ikeda. T., 1971. Changes in respiration rate and in composition of organic matter in Calanus cristatus (Crustacea, Copepoda) under starvation. Bull. Fac. Fish., Hokkaido Univ., 11:280-298.

伊藤嘉昭, 1978. 比較生態学 (第 2 版), 岩波書店, 東京, pp. $1-93$

伊藤嘉昭, 1983. 社会生態学入門, 東京大学出版局, 東京, pp. 20-53.

篇佐 庸, 1981. 生物の適応戦略, サイエンス社, 東京, pp. 28-47.

上田常一, 1970 . 日本淡水エビ類の研究 (第2 版), 園山書 店, 松江, pp. 83-95.

菊池泰二, 1981 . 海産無脊椎動物の繁殖生態と生活史 $\mathrm{I} \sim$ III 海洋と生物， 3:242-246, 360-365, 402-407.

岸 由二, 1978. 卵の大きさはいかに決まるか。生物科学, $30: 48-56$

Kraeuter, J. N., M. Castagna \& R. van Desel, 1982. Egg size and larval survival of Mercenaria mercenaria $(L$.$) and Argopecten irra-$ dians (Lamarck).J. Exp. Mar. Biol. Ecol., $56: 3-8$.

Lynch, M. 1977. Fitness and optimal body size in zooplankton populations. Ecology, 58:763774.

Lynch, M. 1980. The evolution of cladoceran life histories. Quart. Rev. Biol., 55:23-42

Mann, R. H. K. \& C. A. Mills, 1979. Demographic aspects of fish fecundity. In "Fish Phenology"Ed.by P.J. Miller, Academic press, New York, pp. 161-177.

Mashiko, K., 1982. Differences in both the egg size and the clutch size of the freshwater 
prawn Palaemon paucidens de Haan in the Sagami River. Jap. J. Ecol., 32:445-451. Mashiko, K., 1983a. Differences in the egg and clutch size of the prawn Macrobrachium nipponense (de Haan) between brackish and fresh waters of a river. Zool. Mag., 92:1 -9 .

Mashiko, K., 1983b. Evidence of differentiation between the estuarine and upper freshwater populations of the prawn Macrobrachium nipponense. Zool. Mag., 92:180-185.

Mashiko, K., 1983c. Comparison of growth pattern until sexual maturity between the estuarine and upper freshwater populations of the prawn Macrobrachium nipponense (de Haan) within a river. Jap.J. Ecol., 33:207212.

Mashiko, K., 1985. Comparison of survival and development between large and small neonates of a freshwater prawn under starvation conditions. Zool. Sci., 2:397-403.

Nishino, M., 1980. Geographical variations in body size, brood size and egg size of a freshwater shrimp, Palaemon paucidens De Haan, with some discussion on brood habit. Jap. J. Limnol., 41:185-202.

Ogasawara, Y., S. Koshio \& Y. Taki, 1979. Response to salinity in larvae from local populations of the freshwater shrimp, Macrobrachium nipponense. Bull. Japan. Soc. Sci. Fish., 45:937-943.

Peters, R.H., 1983. The Ecological Implications of Body Size, Cambridge Univ. Press. New York, pp. 24-53.

Pianka, E.R., 1978. Evolutinary Ecology(2nd.ed.), Harper \& Row, New York, pp. 125-138.

Robinson, W. R., R. T. Peters \& J. Zimmermann, 1983. The effect of body size and temperature on metabolic rate of organisms. Can. J. Zool, 61:281-288.

Schmidt-Nielsen, K. 1973. Animal Physiology, Cambridge Univ. Press, London, pp. 235-244.

諸喜田茂充, 1979 . 琉球列島の陸水エビ類の分布と種分化に ついて一II. 琉球大学理学部紀要, No. 28; 193-278.

Smith, C.C.\&S.T. Fretwell, 1974. The optimal balance between size and number of off- spring. Amer. Nat., 108:499-506.

Tessier, A. J., L. L. Henrry, C. E. Goulden \&.M.W. Durand, 1983. Starvation in Daphnia: Energy reserves and reproductive allocation. Limnol. Oceanogr., 28:667-676.

Threlkeld, S.T. 1976. Starvation and the size structure of zooplankton communities. Freshwater Biol., 6:489-496.

Werner, E. E., 1974. The fish size, prey size, handling time relation in several sunfishes and implications. J. Fish. Res. Bd. Canada., 31:1531-1536. 